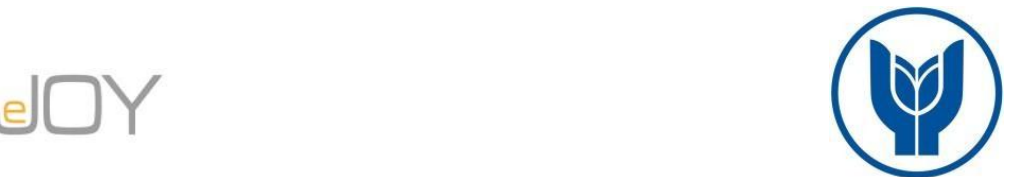

Zengin, S., Yüksel, S., Kartal, M., T. / Journal of Yasar University, 2018, 13/49, 86-100

\title{
Türkiye'deki Düşük Hanehalkı Tasarrufuna Neden Olan Faktörlerin Belirlenmesine Yönelik Bir Araştırma
}

\section{A Research to Determine Factors Causing Low Household Savings in Turkey}

\author{
Sinemis ZENGIN, Türkiye, sinemiszengin@gmail.com \\ Serhat YÜKSEL, Medipol Üniversitesi,Türkiye, serhatyuksel@medipol.edu.tr \\ Mustafa Tevfik KARTAL, Türkiye, mustafatevfikkartal@gmail.com
}

Öz: Ülke ekonomilerinin gelişimi açısından yatırımlar, yatırımların finansmanı ve sürdürülebilirliği açısından ise tasarruflar önemli bir rol oynamaktadır. Yurtiçi tasarrufların yetersiz kaldığında ülkeler yatırımların finansmanı için yurt dış kaynaklara bağımlı hale gelmektedir. Bu durum ise ekonomilerdeki kırılganlıkları artırmaktadır. Bu nedenle düşük tasarruflara sahip ülkeler yurtiçi tasarruflarını artırmak zorundadır. Düşük yurtiçi tasarruflara sahip olan Türkiye'nin tasarrufları artırmak için aksiyon alması kaçınılmazdır. Bunun için öncelikle düşük tasarruflara neden olan hususlar belirlenmelidir. Çalışmamız bu amaca yönelik hazırlanmış ve bu kasamda 289 katılımcı ile anket çalışması yapılmıştır. Analiz sonuçlarına göre gelir ve eğitim düzeyi ile tasarruf oranları arasında doğrusal bir ilişki bulunmaktadır. Diğer taraftan dısarıda yemek yeme alıskanlığı ve kredi kartı kullanım hacmi yüksek olan bireylerde tasarruf eğilimi düsüktür. Calışmamızda elde edilen bir diğer önemli sonuç ise olası bir ek geliri tasarruf etmek yerine harcamayı tercih eden kişilerin normal yaşantılarında da tasarruf yapmamalarıdır. Bu çalışmada belirtilen hususların Türkiye'de düşük tasarruf sorununun çözülebilmesi ve tasarrufların artırllabilmesi için düzenleyici otoritelere yol gösterici olacağl düşünülmektedir.

Anahtar Kelimeler: Anket, Hanehalkı Tasarrufları, İktisadi Büyüme, Türkiye Ekonomisi, Türkiye

Abstract: Savings have substantial role in sustainability and financing of investments which are important for the developments of economies of countries. Countries would be contingent upon foreign resources for financing of investments when domestic savings are inadequate. This condition will increase fragility in economies. For this reason, countries which have low savings should increase domestic savings. Turkey, which has low domestic savings, must take action to increase savings. In order for this, factors resulting in low savings should be determined firstly. The study was intended for this purpose and a survey was made with 289 participants. According to findings, there is a monotonically increasing relationship between income, education level and savings. On the other hand, savings trend is found low for individuals who have dining out habit and high volume of credit cards usage. One another important result is that individuals, who prefer to spend probable additional income instead of making saving, do not make savings in normal life. It is thought that issues stated in this study will guide for regulatory bodies to solve low saving problem and to increase savings in Turkey.

Keywords: Survey, Household Savings, Economic Growth, Turkey Economy, Turkey

\section{Giriş}

Küresel ekonomide ülkeler birbirleri ile rekabet halinde bulunmaktadırlar. Ülkeler rakiplerine rekabet üstünlüğü sağlamak için daha fazla yatırım yapmaya çalışmaktadırlar. Ülkeler yatırımları artırmak için doğrudan yabancı yatırımlar çekmeye çalışmaktadır. Bunun yanı sıra ülke içinde yatırımların yapılması ve teşvik edilmesi önem taşımaktadır. İç yatırımların yapılabilmesi için gerekli kaynak, diğer bir ifade ile sermaye birikimi, ise tasarruflardan sağlanabilmektedir. Bu nedenle kişi ve kurumlar tarafindan tasarruf yapılması, tasarruf kültürünün oluşturulması ve yatırımları destekleyecek tasarruf birikiminin oluşturulması ve sürdürülmesi önemli ekonomik konuların başında gelmektedir.

Bir taraftan yatırımlara kaynak teşkil etmesi, diğer taraftan yatırımların finansmanı sebebi ile istihdam, büyüme, enflasyon ve faiz gibi makroekonomik göstergelerde dolaylı etki oluşturması nedeni ile tasarrufların bulunması ve ülkelerin imkânları dâhilinde yüksek olması dışa bağımlılığın azaltılması ve kalkınma açısından oldukça önemlidir (Feldstein ve Horioka, 1979). Nitekim yatırımların finansmanında tasarruflar yetersiz kaldığında ülkeler yatırımları için gerekli finansman kaynağını bulamamaktadır. Böyle bir durumda ülkeler yatırımların finansmanı için ya yurt dışı kaynak arayışına girecek ya da yatırımları durdurmak veya ertelemek zorunda kalacaklardır. Yurtdışı kaynaklardan sağlanabilecek finansman ise doğrudan yabancı yatırımlar veya doğrudan portföy yatırımları şeklinde gerçekleşebilmektedir. Yatırımlar için finansmanın dış kaynaklardan sağlandığı böyle bir yapıda ise yatırımları dışa bağımlı hale gelen ülkelerin ekonomilerindeki kırılganlık artış gösterecektir (Thaler, 1994).

Türkiye düşük tasarruf problemi yaşayan ülkelerden biridir. Türkiye'nin Gayri Safi Yurtiçi Hasıla (GSYH) gelişimine bakıldığında 2000 yılında 70 milyar TL olan GSYH 2010 yılında 1,09 trilyon TL, 2016 yılında ise 2,59 trilyon TL olarak gerçekleşmiştir (Kalkınma Bakanlığı, 2017; Türkiye Cumhuriyet Merkez Bankası, 2017). Diğer taraftan Türkiye'de tasarrufların gelişimi incelendiğinde, 1990 yılında 84,7 milyon TL olan tasarruflar 2000 
yılında 35,8 milyar TL, 2010 yılında 247,3 milyar TL, 2016 yılında ise 644,5 milyar TL olarak gerçekleşmiştir (Dünya Bankası, 2017). Birlikte değerlendirildiğinde Türkiye'de Tasarruflar/GSYH oranı 2000 yılında \%20,98; 2010 yılında \%21,32 ve 2016 y1lında ise \%24,88 olarak gerçekleşmiştir (Dünya Bankası, 2017). Söz konusu tablodan anlaşılacağı üzere GSYH gelişimine kıyasla Türkiye'de tasarruflar yetersiz kalmaktadır. Bu nedenle Türkiye için düşük tasarruf problemi önemli bir konu olmaktadır.

Gelirin harcanmayan kısmı olarak tanımlanan tasarruflar kamu ve özel kesimin tasarrufları olarak iki ana grup altında sınıflandırılmaktadır. Kamu niteliğine haiz kurumlara ait tasarruflar, kamu tasarrufları altında önemli bir yer tutarken hanehalkı tasarrufları ise özel tasarruflar altında önemli bir yere sahip bulunmaktadır. Bu nedenle Türkiye'de hanehalkı tasarruflarını etkileyen faktörlerin belirlenmesi, düşük tasarruf sorunun çözümü açısından önem taşımaktadır.

Türkiye'nin 2023 yılında ilk 10 küresel ekonomi arasında yer alma hedefi göz önünde bulundurulduğunda, yüksek büyüme rakamlarına ulaşmaya ve bunu sürdürülebilir kılmaya ihtiyacı bulunmaktadır. Ancak yatırımların finansmanı için en önemli ülke içi kaynak olan tasarrufların düşük olması yüksek büyüme hedeflerine ulaşılmasına engel teşkil etmektedir. Dolayısı ile tasarrufların düşüklüğü kaynak açısından Türkiye'nin yurtdışına daha bağımlı hale gelmesine ve daha kırılgan bir ekonomiye sahip olmasına neden olacaktır.

Yukarıdaki hususlar dikkate alındığında bu çalışma Türkiye'de hanehalkı tasarruflarının düşük olmasının nedenlerini belirlemeyi amaçlamaktadır. Bu bağlamda anket yöntemiyle veriler toplanmış ve verilerin analizi ile birlikte Türkiye'de hanehalkı tasarruflarının arttırılabilmesine yönelik öneriler geliştirilmeye çalışılmıştır.

Çalışma beş bölümden oluşmaktadır. Giriş bölümünün ardından ikinci bölümde tasarrufun tanımı, çeşitleri, Türkiye'de tasarrufların gelişimi, Türkiye'de tasarrufların artırılması için yapılan çalışmalar hakkında bilgi verilmiştir. Üçüncü bölümde hanehalkı tasarruflarını etkileyen faktörlere yönelik literatürde yer alan bazı çalışmalar incelenmiştir. Dördüncü bölümde Türkiye'de düşük hanehalkı tasarrufuna yönelik araştırmanın istatistiki sonuçları yorumlanmış ve son bölüm bir değerlendirme ile bitirilmiştir.

\section{Tasarrufun Tanımı, Çeşitleri ve Türkiye'de Tasarrufların Gelişimi}

\subsection{Tasarrufun Tanımı ve Çeşitleri}

Genel olarak tasarruf elde edilen gelirin harcanmayan kısmı olarak tanımlanmaktadır. Klasik iktisatçılara göre tasarruf ile bugünkü tüketim ileri bir tarihe ertelenmektedir (Smith, 1997). Buna karşın Keynes (1980) belirtilen bu düşünceye karşı çıkarak, bugün yapılmış olan tasarrufun gelecekteki tüketimi arttıracağı anlamına gelmediğini ifade etmektedir. Friedman (1957) ise tasarrufları kişilerin geleceğe yönelik aldıkları önlem olarak tanımlamıştır. Söz konusu tanımların işaret ettiği üzere tasarruf yapılmasının birçok nedeni bulunmaktadır. İşsiz kalma, olağandışı masrafların veya deprem gibi olağandışı durumların ortaya çıkması ihtimaline karşı daha güvende olabilmek için tasarruf yapılmaktadır. Belirtilen hususların yanı sıra faiz veya temettü geliri elde etmek için de tasarruf yapilabilmektedir.

Tasarruflar temel olarak kamu tasarrufları ve özel tasarruflar olmak üzere ikiye ayrılmaktadır. Kamu tasarrufları hükümetlerin gerekli harcamaları yapmasının ardından elinde kalan gelirlerdir. Özel tasarruflar ise ülkedeki özel kesim (kişiler ve özel şirketler) tarafından harcanmayan gelirler olarak tanımlanmaktadır. Kamu tasarrufunda hükümetler tarafından yapılan tasarruflar söz konusudur. Hükümetler yapacakları harcamalar için halktan vergi toplarlar. Eğer yaptıkları harcamalar topladıkları vergi gelirlerinden az ise, kamu tasarrufu meydana gelmektedir (Mankiw, 2014). Diğer taraftan özel tasarruflar, kamu tasarrufları dışında kalan tasarrufları ifade etmektedir. Diğer bir ifade ile özel tasarruflar, bir ülkedeki bireyler ve kamuya ait olmayan özel firmalar tarafindan yapılan tasarrufları içermektedir. Dolayısıyla, özel tasarrufları hanehalkı tasarrufu ve özel sektör firmalarının tasarrufu şeklinde iki alt sınıfa ayırmak mümkündür (Athukorala ve Sen, 2004). Hanehalkı tasarrufları özel tasarruflar altında önemli bir yere sahiptir.

Hanehalkı tasarruflarında bir ülkede yaşayan bireylerin elde ettikleri gelirin yaptıkları harcamadan daha fazla olması durumu söz konusudur (Şengür ve Taban, 2016). Hanehalkı tasarrufu kişilerin gelirlerinden yaptıkları harcamaların çıkartılması ile hesaplanmaktadır. Benzer şekilde özel sektörde yer alan firmalara ait tasarruflar da söz konusu firmaların elde ettikleri gelir ile yaptıkları harcamalar arasındaki fark olarak ifade edilmektedir.

Ülkelerin büyümesi yeni yatırımların yapılmasına ve yatırımların sürdürülebilir kılınmasına bağlıdır. Yatırımların arttırılabilmesi için tasarrufların arttırılması temel bir gereklilik olup oldukça önemlidir. Diğer bir ifade ile bir ülkede tasarruflar arttığında yatırımlar için gerekli olan kaynak (finansman) miktarında da artış meydana gelmektedir. Özetle kalkınmanın yolu tasarruflardan geçmektedir. 


\subsection{Türkiye’de Hanehalkı Tasarruflarının Yıllar İtibarıla Gelişimi}

Dünya'da meydana gelen küreselleşme akımına paralel olarak Türkiye ekonomisi 1980'li yıllarda liberalleşmiş ve dışa açık bir ekonomi haline gelmiştir. Türkiye'de 1980 yılında serbest kur politikası benimsenmiş ve 1989 yılında sermaye hareketleri serbest bırakılmıştır. Serbest kur politikası ve sermeye hareketlerinin serbest bırakılması Türkiye'de ekonomik açıdan bir milat olmuştur. Bu süreçten sonra birçok ekonomik göstergede değişimler yaşanmıştır. Değişim yaşanan hususlardan birisi tasarruflardır.

Türkiye'de tasarruflar yıllar itibari ile gelişim göstermektedir. Türkiye'de tasarrufların nominal gelişimine Grafik 1'de yer verilmiştir. Grafik 1'den görüleceği üzere, Türkiye'de tasarruflar 1986 yılına kadar yatay bir seyir izlemiştir. 1987-2002 yılları arasında kısmi artış gösteren tasarruflar, 2003 ve sonrasında ise istikrarlı bir şekilde artı̧̧ göstermektedir. TL bazında tasarruflar 2016 yılında 644,5 milyar TL seviyesine ulaşmasına karşın, ABD doları (USD) kurunda yaşanan yükselişler nedeni ile USD türünde 213,4 milyar USD olarak gerçekleşmiştir (Dünya Bankası, 2017).

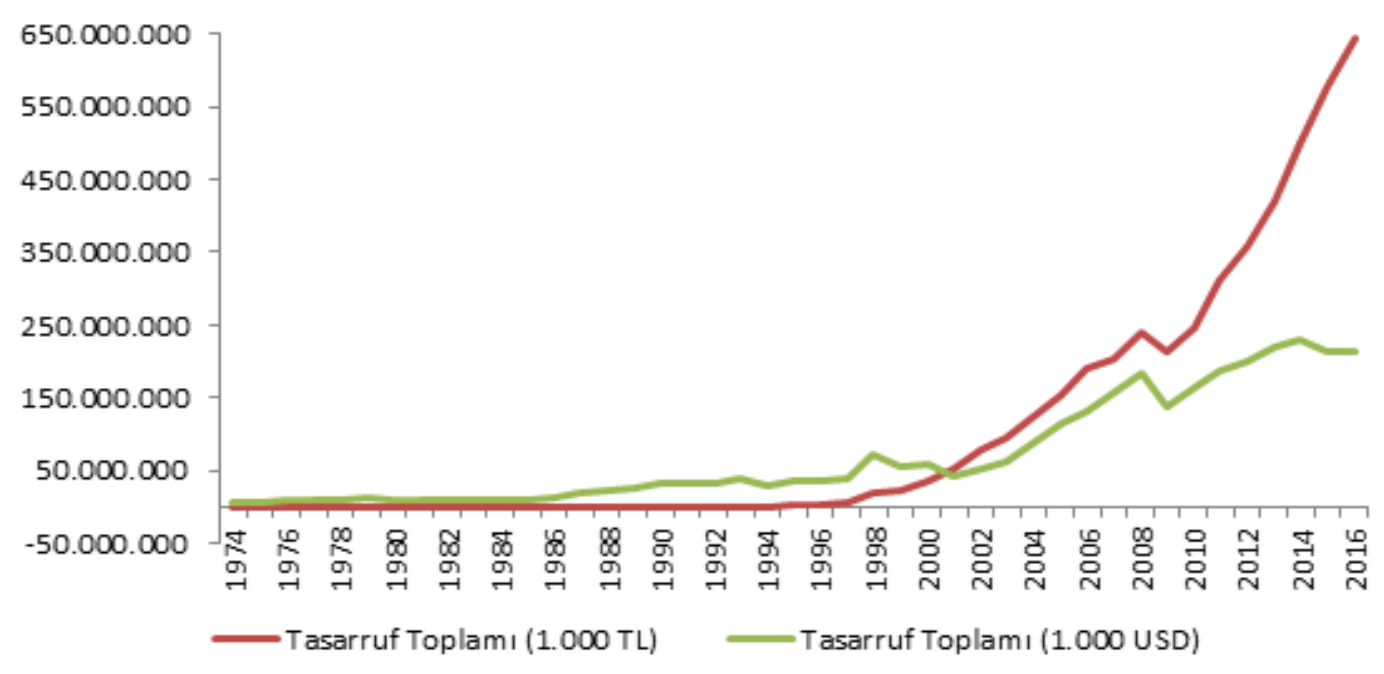

Grafik 1. Türkiye'de Tasarrufların Gelişimi

Kaynak: Dünya Bankası, 2017.

Grafik 1'den anlaşıldığı üzere Türkiye'de tasarruflar ciddi seviyede artış göstermiştir. Bununla birlikte Türkiye'de tasarrufların GSYH'ye kıyasla gelişimine bakmakta fayda bulunmaktadır. Türkiye'de tasarrufların GSYH içindeki payının gelişimine kamu, özel ve toplam tasarruflar detayında Grafik 2'de yer verilmiştir. Grafik 2'den görüleceği üzere, Türkiye'de tasarruflar GSYH'ye kıyasla 1988 yılında \%29,1 olarak en yüksek orana ulaşmıştır. Sonraki yıllarda ise düşüş göstermiştir. Söz konusu düşüşte özellikle 1992 yılı ve sonrasında kamu tasarruflarının genellikle negatif olmasının etkisi büyüktür.

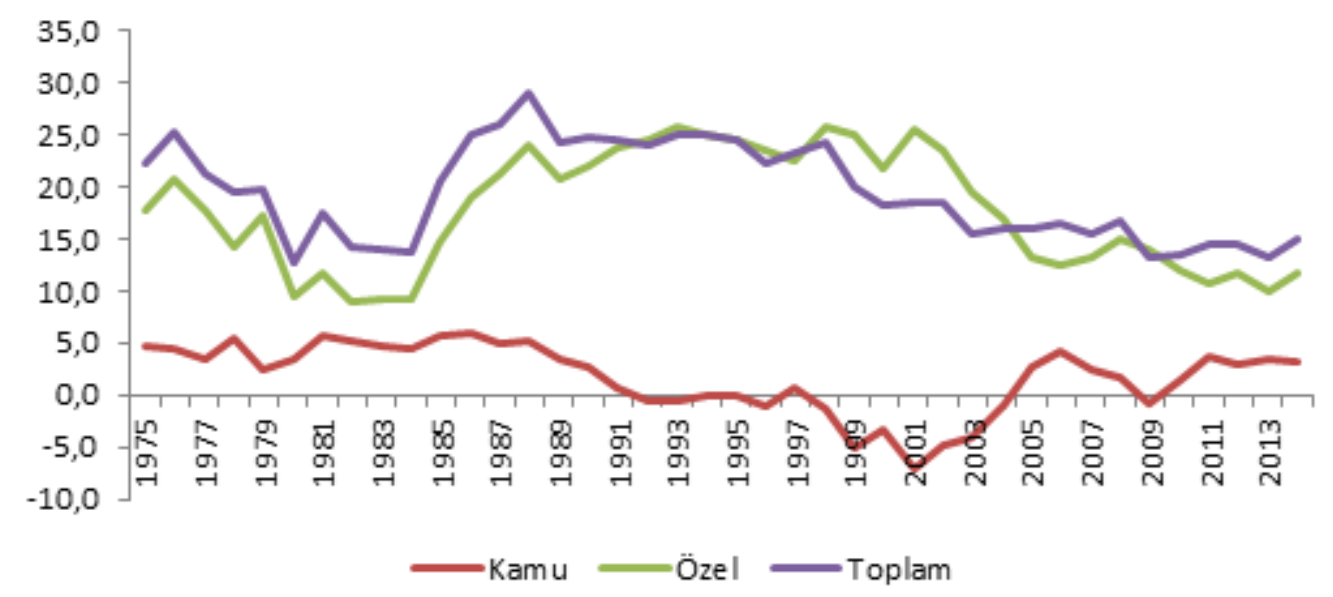

Grafik 2. Türkiye'de Yurt İçi Tasarrufların GSYH İçindeki Payının Gelişimi Kaynak: Kalkınma Bakanlığı, 2017. 
Özellikle 1993, 1997, 2000, 2001, 2004 ve 2009 yıllarında kamu tasarrufları negatif gerçekleşmiştir. Bu durumun temelinde Türkiye'de ve Dünya'da yaşanan krizler yatmaktadır. Ekonomiyi destekleyici ve genişletici hamlelere ağırlık verilmiş ve bu nedenle tasarruf yapma imkânı bulunamadığından kamu tasarrufları negatif seyretmiştir. Özel tasarruflar ise kamu tasarruflarının oldukça üzerindedir. Ek olarak Türkiye'deki kamu ve özel tasarrufların genel olarak ters yönlü ilişkiye sahip olduğu görülmektedir.

2014 yılında GSYH'ye oranla kamu tasarrufları \%3,2, özel tasarruflar \%11,7 ve toplam tasarruflar \%14,9 olarak gerçekleşmiştir (Kalkınma Bakanlığı, 2017). Grafik 2'den anlaşılacağı üzere Türkiye düşük tasarruf problemi ile karşı karşıya bulunmaktadır. Sonraki yıllarda ciddi anlamda ekonomik büyümeyi hedefleyen Türkiye için söz konusu problemin önemli bir engel oluşturmaktadır. Düşük tasarruf oranları sebebiyle yapılacak yatırımlar için yurt dışı kaynaklara bağlı kalınmakta ve bu durum Türkiye ekonomisini dış şoklara karşı kırılgan hale getirmektedir.

\subsection{Türkiye'de Tasarrufların Artırılması İçin Yapılan Çalışmalar}

Türkiye düşük tasarruf problemi yaşayan ülkelerden biridir. Özellikle 1999 yılından bu yana Türkiye'nin tasarruf oranlarında ciddi anlamda düşüş meydana gelmektedir. 1998 yılında \%24,3 olan tasarruf oranı 2014 yılında \%14,9 seviyesine gerilemiştir. Ayrıca 2014 yılında Dünya ortalaması \%25 iken Türkiye'de tasarruf oranı \% 14,9 ile Dünya ortalamasının oldukça altında gerçekleşmiştir (Özcan vd., 2003; Dünya Bankası, 2017; Kalkınma Bakanlığı, 2017).

Türkiye'de düşük tasarruflar ekonomi yönetimi tarafından da yakından izlenmektedir. Tasarrufların artırılmasına yönelik çalışmalar yapılmaktadır. Bu kapsamda bankacılıktaki mevduatlardan kazanılan faizlerden kesilen vergi (stopaj) oranının ve bankaların mevduatlar için Türkiye Cumhuriyeti Merkez Bankası'na yatırdıkları zorunlu karşılıkların daha uzun vadelerde daha düşük uygulanması adımları atılmıştır. Ayrıca bireysel emeklilik sisteminin hayata geçirilmiştir. Bireysel emeklilik sistemi kapsamında sisteme dâhil olan katılımcılara devlet katkısı sağlanmıştır. Diğer taraftan otomatik bireysel emeklilik sisteminin hayata geçirilmiştir. Söz konusu bu adımlar tasarrufların artırılmasına yönelik çalışmalardan bazılarıdır. Ayrıca Hazine Müsteşarlığı tarafından altın tahvili ve altın kira sertifikası ihraç edilmesi, tasarrufların artırılması çalışmaları kapsamında son zamanlarda atılan önemli adımlardan birisi olarak değerlendirilmektedir.

\section{Literatür Taraması}

Literatürde hanehalkı tasarruflarını etkileyen faktörlerin belirlenmesine yönelik çok sayıda çalışma bulunmaktadır. Hanehalkı tasarruflarına yönelik çalışmalar yurt dışında ve yurt içinde yapılan çalışmalar olmak üzere iki başlık halinde incelenecektir.

\subsection{Yurt Dışııda Yapılan Çalışmalar}

Yurt dışı literatürde hanehalkı tasarruflarını etkileyen faktörler ile ilgili çeşitli çalışmalar bulunmaktadır. Literatür taraması kapsamında bu çalışmalar arasından seçilenlere Tablo 1'de yer verilmiştir.

Tablo 1. Yurt Dışında Yapılmış Bazı Çalışmalar

\begin{tabular}{|c|c|c|c|c|c|}
\hline Yazar & Yil & Kapsam & Dönem & Yöntem & Sonuç \\
\hline $\begin{array}{l}\text { Corbo ve } \\
\text { Schmidt- } \\
\text { Hebbel }\end{array}$ & 1991 & $\begin{array}{l}13 \text { Gelişmekte } \\
\text { Olan Ülke }\end{array}$ & $\begin{array}{l}1980- \\
1987\end{array}$ & $\begin{array}{l}\text { Panel Veri } \\
\text { Analizi }\end{array}$ & $\begin{array}{l}\text { Hanehalkı tasarrufları faiz oranı, gelir ve } \\
\text { enflasyona duyarlıdır. }\end{array}$ \\
\hline $\begin{array}{l}\text { Schmidt- } \\
\text { Hebbel vd. }\end{array}$ & 1992 & $\begin{array}{c}\text { Birleşmiş } \\
\text { Milletler Üyesi } \\
10 \text { Ülke } \\
\end{array}$ & $\begin{array}{l}1970- \\
1985\end{array}$ & $\begin{array}{l}\text { Regresyon } \\
\text { Analizi }\end{array}$ & $\begin{array}{l}\text { Geliri yüksek olan kişilerin daha fazla } \\
\text { tasarruf yapmaktadır. }\end{array}$ \\
\hline Edwards & 1995 & 23 Ülke & $\begin{array}{l}1970- \\
1992\end{array}$ & $\begin{array}{l}\text { Panel Veri } \\
\text { Analizi }\end{array}$ & $\begin{array}{l}\text { Ülkenin ekonomik büyüme oranı ile } \\
\text { hanehalkı tasarrufları arasında doğru orantı } \\
\text { bulunmaktadır. }\end{array}$ \\
\hline Masson vd. & 1995 & $\begin{array}{c}21 \text { Gelişmiş ve } \\
23 \text { Gelişmekte } \\
\text { Olan Ülke } \\
\end{array}$ & $\begin{array}{c}1971- \\
1993\end{array}$ & $\begin{array}{l}\text { Regresyon } \\
\text { Analizi }\end{array}$ & $\begin{array}{l}\text { Faiz oranları hanehalkı tasarrufları üzerinde } \\
\text { etkilidir. }\end{array}$ \\
\hline Browning & 1995 & Kanada & $\begin{array}{c}1978- \\
1990\end{array}$ & Anket & $\begin{array}{l}\text { Evli çiftlerin daha fazla tasarruf yaptığ } 1 \\
\text { belirlenmiştir. }\end{array}$ \\
\hline $\begin{array}{l}\text { Wakabayashi } \\
\text { ve MacKellar }\end{array}$ & 1999 & Çin & $\begin{array}{l}1995- \\
1997\end{array}$ & $\begin{array}{l}\text { Regresyon } \\
\text { Analizi }\end{array}$ & $\begin{array}{l}\text { Hanehalkı tasarrufları kişilerin yaşları ile } \\
\text { orantılıdır. }\end{array}$ \\
\hline
\end{tabular}




\begin{tabular}{|c|c|c|c|c|c|}
\hline Yazar & Yil & Kapsam & Dönem & Yöntem & Sonuç \\
\hline Kwack & 2003 & Güney Kore & $\begin{array}{l}1977- \\
2002\end{array}$ & $\begin{array}{l}\text { Zaman } \\
\text { Serisi } \\
\text { Analizi }\end{array}$ & $\begin{array}{l}\text { Ülkenin ekonomik büyümesi ile hanehalkı } \\
\text { tasarrufları arasında doğru orantı } \\
\text { bulunmaktadır. }\end{array}$ \\
\hline $\begin{array}{l}\text { Paiva ve } \\
\text { Jahan }\end{array}$ & 2003 & Brezilya & $\begin{array}{l}1965- \\
2000\end{array}$ & $\begin{array}{l}\text { Regresyon } \\
\text { Analizi }\end{array}$ & $\begin{array}{lccc}\text { Kamu tasarruflarının } & \text { artması } & \text { özel } \\
\text { tasarrufları azaltmaktadır. } & & \\
\end{array}$ \\
\hline $\begin{array}{l}\text { Mirach ve } \\
\text { Hailu }\end{array}$ & 2014 & Etiyopya & 2013 & Anket & $\begin{array}{l}\text { Düşük gelir, yüksek enflasyon, işsizlik oranı } \\
\text { ve eğitim düzeyi hanehalkı tasarrufları } \\
\text { üzerinde etkilidir. }\end{array}$ \\
\hline Le Blanc vd. & 2015 & 15 AB Ülkesi & $\begin{array}{l}2010- \\
2011\end{array}$ & Anket & $\begin{array}{l}\text { Hanehalkı tasarrufu ile gelir arasında doğru } \\
\text { orantı bulunmaktadır. }\end{array}$ \\
\hline $\begin{array}{l}\text { Finlay ve } \\
\text { Price }\end{array}$ & 2015 & Avustralya & $\begin{array}{l}2009- \\
2010\end{array}$ & $\begin{array}{l}\text { Regresyon } \\
\text { Analizi }\end{array}$ & $\begin{array}{l}\text { Yüksek gelire sahip olanlar daha fazla } \\
\text { tasarrufta bulunmaktadır. }\end{array}$ \\
\hline Wan & 2015 & Çin & $\begin{array}{l}1995- \\
2010\end{array}$ & Anket & $\begin{array}{l}\text { Ev fiyatlarındaki artış ile hanehalkı } \\
\text { tasarrufları arasında aynı yönde bir ilişki } \\
\text { bulunmaktadır. }\end{array}$ \\
\hline Zhuk & 2015 & Ukrayna & $\begin{array}{l}1993- \\
2013\end{array}$ & $\begin{array}{l}\text { Regresyon } \\
\text { Analizi }\end{array}$ & $\begin{array}{l}\text { GSYH rakamının artması hanehalkı } \\
\text { tasarruflarının yükselmesine yol açmaktadır. }\end{array}$ \\
\hline Bebczuk vd. & 2015 & $\begin{array}{l}\text { 10 Latin } \\
\text { Amerika } \\
\text { Ülkesi }\end{array}$ & $\begin{array}{l}2003- \\
2012\end{array}$ & Anket & $\begin{array}{l}\text { Hanehalkı geliri ile tasarruf arasında doğru } \\
\text { orantı bulunmaktadır. }\end{array}$ \\
\hline Pan & 2016 & Çin & $\begin{array}{l}1995- \\
2002\end{array}$ & $\begin{array}{c}\text { DFL } \\
\text { Yöntemi }\end{array}$ & $\begin{array}{l}\text { Kentlerde yaşayanların } \\
\text { gelirleri doğru orantılıdır. }\end{array}$ \\
\hline Hashim vd. & 2017 & Malezya & $\begin{array}{l}2006- \\
2015\end{array}$ & Regresyon & $\begin{array}{l}\text { Tasarruflar faiz oranları ve tüketici fiyat } \\
\text { endeksi ile pozitif, kişi başına gelir ile } \\
\text { negatif ilişkilidir. }\end{array}$ \\
\hline
\end{tabular}

\section{Kaynak: Yazarlar}

Pan (2016) çalışmasında Çin'deki hanehalkı tasarruflarını etkileyen faktörleri incelemiştir. Söz konusu çalışmada kişiler kentte ve kırsal alanda yaşayanlar olmak üzere 2 farklı gruba ayrılmış ve 1995-2002 dönem aralığındaki veriler analizde kullanılmıştır. Çalışma sonucunda kentte yaşayan insanların tasarruflarının gelirleri ile doğru orantılı olduğu belirlenmiştir. Le Blanc ve diğerleri (2015), Finlay ve Price (2015), Bebczuk ve diğerleri (2015), Mirach ve Hailu (2014), Schmidt-Hebbel, Webb ve Corsetti (1992) de farklı yöntemler kullanarak aynı sonuca ulaşmışlardır. Wan (2015) tarafından yapılan çalışmada ise Çin'deki hanehalkı tasarruflarının ev fiyatlarından etkilediği belirlenmiştir.

Zhuk (2015) Ukrayna'daki hanehalkı tasarruflarının belirleyicilerine yönelik araştırma yapmıştır. Çalışmada 1993-2003 yılları arasındaki veriler regresyon yöntemi ile analiz edilmiştir. Çalışma sonucunda ülkenin GSYH rakamı ile hanehalkı tasarrufları arasında doğru orantı bulunduğu belirlenmiştir. Kwack (2003) ve Edwards (1995) da farklı yöntem kullanarak benzer sonuca ulaşmışlardır. Paiva ve Jahan (2003) Brezilya'daki hanehalkı tasarrufları ile kamu tasarrufları arasında ters yönlü bir ilişsi bulunduğunu tespit etmişlerdir.

Wakabayashi ve MacKellar (1999) çalışmalarında Çin'deki hanehalkı tasarruflarına yönelik araştırma yapmışlardır. Çalışma sonucunda hanehalkı tasarruflarının kişilerin yaşları ile doğru orantılı olduğu belirlenmiştir. Browning (2000) Kanada'daki evli çiftlerin daha fazla tasarruf yapabildiklerini tespit etmiştir. Masson, Bayoumi ve Samiei (1995) 21 gelişmiş ve 23 gelişmekte olan ülke üzerine yaptıkları çalışmada, faiz oranlarının hanehalkı tasarrufları üzerinde etkili olduğu sonucuna ulaşmışlardır. Corbo ve Schmidt-Hebbel (1991) de panel veri analizi kullanarak yaptıkları çalışmada benzer sonuca ulaşmışlardır.

\subsection{Yurt İçinde Yapılan Çalışmalar}

Türkiye'de hanehalkı tasarrufları ile ilgili çeşitli çalışmalar bulunmaktadır. Literatür taraması kapsamında bu çalışmalar arasından seçilenlere Tablo 2'de yer verilmiştir.

Tablo 2. Türkiye'de Yapılmıș Bazı Çalıșmalar

\begin{tabular}{|c|c|c|c|l|}
\hline Yazar & Yıl & Yöntem & Dönem & \multicolumn{1}{|c|}{ Sonuç } \\
\hline Düzgün & 2009 & Regresyon & $\begin{array}{c}1987- \\
2007\end{array}$ & $\begin{array}{l}\text { Kamu tasarrufu ve enflasyon oranı ile özel tasarruflar } \\
\text { arasında ters yönlü bir ilişki bulunmaktadır. }\end{array}$ \\
\hline Van vd. & 2009 & Regresyon & $\begin{array}{c}2004- \\
2005\end{array}$ & $\begin{array}{l}\text { Konut kredilerindeki artış, hanehalk1 tasarruflarındaki } \\
\text { düşüklüğün temel sebeplerinden biridir. }\end{array}$ \\
\hline
\end{tabular}




\begin{tabular}{|c|c|c|c|c|}
\hline Yazar & Yil & Yöntem & Dönem & Sonuç \\
\hline $\begin{array}{c}\text { Cilasun ve } \\
\text { Kırdar }\end{array}$ & 2009 & $\begin{array}{c}\text { Betimleyici } \\
\text { İstatistik }\end{array}$ & $\begin{array}{l}2002- \\
2006 \\
\end{array}$ & Hanehalkı tasarrufları, eğitim ve yaş ile doğru orantılıdır. \\
\hline $\begin{array}{l}\text { Çolak ve } \\
\text { Öztürkler }\end{array}$ & 2012 & Regresyon & 2010 & $\begin{array}{l}\text { Hanehalkı tasarrufları ile GSYH rakamı arasında doğru } \\
\text { orantı bulunmaktadır. }\end{array}$ \\
\hline $\begin{array}{l}\text { Özlale ve } \\
\text { Karakurt }\end{array}$ & 2012 & Regresyon & $\begin{array}{l}1987- \\
2010\end{array}$ & $\begin{array}{l}\text { Faiz oranlarının yükselmesi tasarrufları artırmaktadır. Kişi } \\
\text { başına milli gelir ile tasarruflar arasında bir ilişki } \\
\text { bulunmamaktadır. }\end{array}$ \\
\hline Matur vd. & 2012 & $\begin{array}{l}\text { Johansen Eş } \\
\text { bütünleşme } \\
\text { Analizi }\end{array}$ & $\begin{array}{l}1977- \\
2008\end{array}$ & $\begin{array}{l}\text { GSYH rakamı ile hanehalkı tasarrufları arasında doğru } \\
\text { orantı bulunmaktadır. }\end{array}$ \\
\hline Uygur & 2012 & $\begin{array}{c}\text { Johansen Eş } \\
\text { bütünleşme } \\
\text { Analizi }\end{array}$ & $\begin{array}{l}1987- \\
1998\end{array}$ & $\begin{array}{l}\text { Reel kur oranındaki artış ve kamu tasarrufları, özel } \\
\text { tasarrufları etkilemektedir. }\end{array}$ \\
\hline $\begin{array}{l}\text { Ceritoğlu } \\
\text { ve Eren }\end{array}$ & 2014 & Regresyon & 2010 & \begin{tabular}{|l}
$\begin{array}{l}\text { Üniversite mezunlarının } \\
\text { tasarrufları arttırmaktadır. }\end{array}$ \\
sayısının artması, hanehalk1
\end{tabular} \\
\hline $\begin{array}{l}\text { Hamarat } \\
\text { ve Özen }\end{array}$ & 2015 & $\begin{array}{l}\text { Kanonik } \\
\text { Korelasyon } \\
\text { Analizi } \\
\end{array}$ & 2010 & $\begin{array}{l}\text { Hanehalkı tasarrufları ve gelir arasında doğru orantılı bir } \\
\text { ilişki bulunmaktadır. }\end{array}$ \\
\hline $\begin{array}{l}\text { Şengür ve } \\
\text { Taban }\end{array}$ & 2016 & Logit & $\begin{array}{l}2002- \\
2013\end{array}$ & $\begin{array}{l}\text { Aylık gelir ve eğitim seviyesi, hanehalkı tasarrufları ile } \\
\text { doğru orantılıdır. Otomobil sahipliği ise hanehalkı } \\
\text { tasarrufları ile ters orantılıdır. }\end{array}$ \\
\hline $\begin{array}{l}\text { Barış ve } \\
\text { Şahin }\end{array}$ & 2017 & $\begin{array}{c}\text { Lojistik } \\
\text { Regresyon }\end{array}$ & - & $\begin{array}{l}\text { Yaş ve gelir düzeyi hanehalkı tasarruf davranışında etkili } \\
\text { olmaktadır. }\end{array}$ \\
\hline Şahin & 2017 & Panel veri & $\begin{array}{l}2000- \\
2014\end{array}$ & $\begin{array}{l}\text { Yüksek gelirli ülkelerde ve üst-orta gelirli ülkelerde yurt içi } \\
\text { tasarruflar ile mevduat faizleri, kişi başına düşen gelir artışı, } \\
\text { enflasyon, kentsel ve kırsal nüfus artışı arasında pozitif } \\
\text { ilişki; işsizlik oranı ile negatif ilişki bulunmaktadır. } \\
\text { Düşük orta gelirli ülkelerde, yurt içi tasarruflarla mevduat } \\
\text { faizleri, kişi başına düşen gelir artışı ve enflasyon arasında } \\
\text { pozitif ilişki; işsizlik oranı, kentsel ve kırsal nüfus artışı ile } \\
\text { negatif ilişki bulunmaktadır. }\end{array}$ \\
\hline Uçgun & 2017 & $\begin{array}{l}\text { Granger Eş } \\
\text { bütünleşme } \\
\text { Analizi }\end{array}$ & $\begin{array}{l}2000- \\
2014\end{array}$ & $\begin{array}{l}\text { GSYH artışı tasarrufların artmasında önemli bir faktördür. } \\
\text { Kamu ve hanehalkı harcamaları ise tasarrufları olumsuz } \\
\text { etkilemektedir. }\end{array}$ \\
\hline
\end{tabular}

Kaynak: Yazarlar

Şengür ve Taban (2016) çalışmalarında hanehalkı tasarruflarının gelir dışındaki belirleyicilerini incelemişlerdir. 2002-2013 yılları arasındaki verilerin kullanıldığı çalışmada logit yöntemi tercih edilmiştir. Elde edilen sonuçlara göre, aylık gelir ve eğitim seviyesi hanehalkı tasarruflarını etkilemektedir. Ayrıca, otomobil sahipliği ile tasarruflar arasında ters yönlü bir ilişki bulunmuştur. Hamarat ve Özen (2015), Ceritoğlu ve Eren (2014), Cilesun ve Kırdar (2009) da farklı yöntemler kullanarak yaptıkları analizlerde aynı sonuçlara ulaşmışlardır.

Çolak ve Öztürkler (2012) Türkiye'deki hanehalkı tasarruf eğilimini incelemişlerdir. Çalışma sonucunda tasarruf oranları ile GSYH rakamı arasında pozitif bir ilişki bulunmuştur. Matur, Sabuncu ve Bahçeci (2012) de Johansen eş bütünleşme analizi kullanarak gerçekleştirdikleri çalışmada aynı sonuca ulaşmışlardır. Diğer taraftan, Özlale ve Karakurt (2012) regresyon analizi kullanarak gerçekleştirdikleri çalışmalarında milli gelir ile tasarruf miktarı arasında bir ilişki bulunmadığını sonucuna ulaşmışlardır.

Uygur (2012) çalışmasında Türkiye'deki özel ve kamu tasarruflarını etkileyen faktörleri incelemiştir. 19871998 yılları arasındaki verilerin kullanıldığı çalışmada, reel kur oranındaki artış ile kamu tasarruflarının özel tasarrufları etkilediği sonucuna ulaşılmıştır. Düzgün (2009) de farklı bir yöntem kullanarak yaptığı çalışmada benzer sonuca ulaşmıştır. Belirtilen çalışmalara ek olarak, Van Rijckeghem ve Üçer (2009) konut kredilerindeki artışın hanehalkı tasarruflarındaki düşüklüğün sebebi olduğu sonucuna ulaşmışlardır.

\section{Türkiye'deki Düşük Hanehalkı Tasarrufuna Yönelik Bir Araştırma}

\subsection{Amaç, Yöntem ve Anket Sorulart}

Bu çalışmada Türkiye'de düşük hanehalkı tasarruflarına neden olan hususların belirlenmesi ve mevcut durumun analiz edilerek öneriler geliştirilmesi amaçlanmıştır. Bu nedenle literatürde yer alan çalışmalar incelenmiştir. 
Literatürdeki çalışmalarda hanehalkı tasarruflarını etkileyen hususlara yönelik kullanılan değişkenlere Tablo 3 'te yer verilmiştir.

Tablo 3. Tasarruflara Etki Eden Değişkenler

\begin{tabular}{|l|l|}
\hline \multicolumn{1}{|c|}{ Değişken } & \multicolumn{1}{c|}{ Kaynaklar } \\
\hline $\begin{array}{l}\text { Acil Durumlar İçin Para Tutma } \\
\text { Alışkanlı̆̆ }\end{array}$ & Hira (1987), Lee vd. (2000), Anong ve Devaney (2010), Nosi vd. (2014), \\
\hline Araba Sahipliği & Şengür ve Taban (2016) \\
\hline $\begin{array}{l}\text { Banka Kartı } \\
\text { Kredi Kartı Tercihi }\end{array}$ & Hira (1987), Anong ve Devaney (2010), Lee vd. (2000) \\
\hline Cinsiyet & Nosi vd. (2014) \\
\hline Çalışma Şekli & Atalay vd. (2014) \\
\hline Çocuk Sahipliği & Xiao ve Noring (1994), Xiao ve Anderson (1997), Gärling (2010) \\
\hline Ek Gelir Harcama Alışkanlı̆̆ı & Nosi vd. (2014) \\
\hline Ev Sahipliği & $\begin{array}{l}\text { Avery ve Kennickell (1991), Bosworth vd. (1991), Browning ve Lusardi } \\
\text { (1996), Chen ve DeVaney (2001), Rha vd. (2006), Yuh ve Hanna (2010) }\end{array}$ \\
\hline Gelir & $\begin{array}{l}\text { Schmidt-Hebbel, Webb ve Corsetti (1992), Mirach ve Hailu (2014), Bebczuk } \\
\text { vd. (2015), Finlay ve Price (2015), Le Blanc vd. (2015), Pan (2016) }\end{array}$ \\
\hline Hayat Tarzı & Gärling (2010), Fisher ve Anong (2012), Hirsh (2015) \\
\hline Kredi Kartı Adedi & Hira (1987), Anong ve Devaney (2010), Lee vd. (2000) \\
\hline Kredi Kartı Kullanımı & Hira (1987), Anong ve Devaney (2010), Lee vd. (2000) \\
\hline Kredi Sahipliği & Livingstone ve Lunt (1993) \\
\hline Medeni Durum & Browning (2000), Du ve Wei (2013) \\
\hline Vadeli Hesap Sahipliği & Carvalho vd. (2016) \\
\hline
\end{tabular}

Literatürde yer alan çalışmalarda kullanılan değişkenler incelendiğinde söz konusu değişkenlerin tasarruflar üzerinde pozitif ve negatif etkiler oluşturması beklenmektedir. Bireylerin tasarruf etme nedenlerine etki eden unsurların belirlenebilmesi amacıyla literatürdeki çalışmalar göz önünde bulundurularak yukarıda yer verilen 15 değişkeni kapsayan anket soruları hazırlanmıştır. Anket sorularına Ek 1'de yer verilmiş olup anket çalışması Surveymonkey web sitesi üzerinden yapılmıştır. Anket çalışması 289 kişi ile tamamlanmış olup hata payı \% $\%$,76 olarak hesaplanmıştır.

\subsection{Betimleyici İstatistikler}

Araştırmada katılımcıların cinsiyeti, medeni durumu, eğitim düzeyi, aylık hanehalkı geliri ve çalışma şekline ilişkin bilgiler alınarak betimleyici istatistikler elde edilmiştir. Toplamda 289 katılımcının ilgili sorulara verdikleri yanıtların dağılımına Tablo 4’te yer verilmiştir.

Tablo 4. Katılımcıların Demografik Özelliklerine Ait Betimleyici İstatistikler

\begin{tabular}{|c|c|c|c|c|c|c|c|}
\hline Özellik & Detay & Frekans & $\%$ & Özellik & Detay & Frekans & $\%$ \\
\hline \multirow{3}{*}{ Cinsiyet } & Erkek & 164 & 56,7 & \multirow{6}{*}{$\begin{array}{c}\text { Aylık } \\
\text { hanehalkı } \\
\text { geliri }\end{array}$} & $0-1.000 \mathrm{TL}$ & 1 & 0,3 \\
\hline & Kadın & 125 & 43,3 & & $1.001-3.000 \mathrm{TL}$ & 46 & 15,9 \\
\hline & Toplam & 289 & 100,0 & & $3.001-5.000 \mathrm{TL}$ & 60 & 20,8 \\
\hline \multirow{3}{*}{$\begin{array}{l}\text { Medeni } \\
\text { Durum }\end{array}$} & Evli & 125 & 43,3 & & $5.001-10.000 \mathrm{TL}$ & 100 & 34,6 \\
\hline & Bekâr & 164 & 56,7 & & 10.001 TL ve üzeri & 82 & 28,4 \\
\hline & Toplam & 289 & 100,0 & & Toplam & 289 & 100,0 \\
\hline \multirow{6}{*}{ Eğitim } & Ortaokul & 13 & 4,5 & \multirow{6}{*}{$\begin{array}{l}\text { Çalışma } \\
\text { Şekli }\end{array}$} & Çalışmıyor & 9 & 3,1 \\
\hline & Lise & 15 & 5,2 & & Kamu çalışanı & 15 & 5,2 \\
\hline & \begin{tabular}{|l|} 
Ön Lisans \\
/ Lisans \\
\end{tabular} & 151 & 52,2 & & Öğrenci & 7 & 2,4 \\
\hline & Yüksek Lisans & 110 & 381 & & Özel sektör çalışanı & 249 & 86,2 \\
\hline & / Doktora & & & & Serbest Meslek & 9 & 3,1 \\
\hline & Toplam & 289 & 100,0 & & Toplam & 289 & 100,0 \\
\hline
\end{tabular}

Tablo 4'ten görüleceği üzere, ankete katılanların büyük kısmı lisans mezunlarından ve erkeklerden oluşmaktadır. Katılımcılar arasında erkekler \%56,7; kadınlar ise \%43,3 paya sahiptirler. Katılımcıların 151 'i lisans mezunu olup toplam katılımcıların \%52,2'sini oluşturmaktadır. Ankete katılanların çoğunluğu bekârdır. Katılımcıların 164'ü bekâr olup toplam katılımcıların \%56,7'sini oluşturmaktadır. 
Ankete katılanların çoğunluğu 5.001-10.000 TL arasında hanehalkı gelirine sahip bulunmaktadır. Katılımcıların 100’ü söz konusu gelir aralığında yer alıp toplamın \%34,6’sını oluşturmaktadır. Diğer taraftan katılımcıların \%86,2'sini oluşturan 249 katılımcının özel sektör çalışanı olduğu, 9 adet katılımcının çalışmadığı ve 7 adet katılımcının ise öğrenci olduğu görülmüştür.

\subsection{Istatiksel Analizler}

\subsubsection{Cronbach Alfa Testi}

Anket sonuçları analiz edilmeden önce iç tutarlılık analizi yapılmalıdır. İç tutarlılık analizi için çalışmada Cronbach Alfa (alfa) testi kullanılmıştır. Bu test ölçekte yer alan soruların homojen bir yapı gösteren bir bütünü ifade edip etmediğini araştırmaktadır. Alfa ağırlıklı standart değişism ortalamasıdır ve bir ölçekteki soruların varyansları toplamının genel varyansa oranlanması ile elde edilir. Alfa katsayısı 0 ile 1 arasında bir değer almaktadır. Bu katsayıya bağlı olarak ölçeğin iç tutarlılığı şu şekilde gösterilmektedir (Kalaycı, 2009):

- $\quad 0,00 \leq(\alpha)<0,40$ ise ölçek güvenilir değildir.

- $\quad 0,40 \leq(\alpha)<0,60$ ise ölçeğin güvenilirliği düşüktür.

- $\quad 0,60 \leq(\alpha)<0,80$ ise ölçek oldukça güvenilirdir.

- $\quad 0,80 \leq(\alpha)<1,00$ ise ölçek yüksek derecede güvenilirdir.

Araştırmada sorgulanan tüm sorular için ve oluşması muhtemel alt gruplar için alfa katsayısı ile iç tutarlılık hesaplanmıştır (Cronbach, 1951). Hesaplanan katsayılara Tablo 5’te yer verilmiştir.

Tablo 5. Cronbach Alfa Katsayis1

\begin{tabular}{|l|c|}
\hline \multicolumn{1}{|c|}{ Faktör } & Cronbach Alpha \\
\hline Genel & 0,737 \\
\hline Motivasyon unsurları & 0,619 \\
\hline Banka ürünleri kullanım alışkanlığ1 & 0,685 \\
\hline Yaşam tarzı & 0,616 \\
\hline Borçlanma alışkanlığı & 0,608 \\
\hline
\end{tabular}

Alfa değeri motivasyon unsurları için 0,619; banka ürünleri kullanım alışkanlığı için 0,685; yaşam tarzı için 0,616; borçlanma alışkanlığ1 için 0,608 ve genel olarak 0,737 olarak elde edilmiştir. Söz konusu test sonuçları eşik değer olan 0,60 değerinden büyük olduğu için, ölçeğin iç tutarlılığının yüksek olduğunu göstermektedir.

\subsubsection{Faktör Analizi}

Araştırmada tasarruflar ile ilgili sorulan 30 adet ifade için Faktör Analizi uygulanarak kavramsal anlamlılığa ulaşılabilecek daha az sayıda faktör oluşturulmaya çalışılmıştır. Faktör Analizinin uygulanabilmesi için temel iki varsayımın sağlanması gerekmektedir; Kaiser-Meyer-Olkin (KMO) ve Bartlett Küresellik testi. KMO test istatistiği için istenilen değerin 0,50’nin üzerinde olması gerektiği aksi takdirde değişkenlerin faktörleştirilemeyeceği ileri sürülmektedir. Bartlett Küresellik testinde ise H0 hipotezinin reddedilmesi faktör analizine devam edebilmek için gerekli bir durumdur (Çokluk vd., 2012). Bartlett Küresellik testine ait hipotezler aşağıdaki gibidir:

$\mathrm{H}_{0}$ : Korelasyon matrisi birim matrise eşittir $(\mathrm{R}=\mathrm{I})$

$\mathrm{H}_{1}$ : Korelasyon matrisi birim matrise eşit değildir $(\mathrm{R} \neq \mathrm{I})$

Tablo 6. KMO ve Bartlett Küresellik Testi

\begin{tabular}{|c|c|c|}
\hline \multicolumn{2}{|c|}{ Kaiser-Meyer-Olkin (KMO) İstatistiği } & 0,745 \\
\hline \multirow{3}{*}{ Bartlett Küresellik Testi } & Approx. Chi-Square & 1868,539 \\
\hline & df & 435 \\
\hline & Sig. & 0,000 \\
\hline
\end{tabular}

Çalışmamızda kullandığımız anket verilerine ilişkin Kaiser-Meyer-Olkin (KMO) değeri 0,745, Bartlett's küresellik testi anlamlılık değeri ise 0.000 olarak belirlenmiştir. Söz konusu sonuçlar anket verilerinin faktör analizine uygun olduğunu ve faktör analizinin uygulanmasında herhangi bir sakınca olmadığını göstermektedir. Ayrıca bahsi geçen anket dört farklı boyutta incelenmektedir. İlgili unsurlara yönelik faktör analizi ve güvenirlik analizi sonuçlarına Tablo 7'de yer verilmiştir. 
Tablo 7. Faktör ve Güvenilirlik Analizi Sonuçları

\begin{tabular}{|c|c|c|c|c|c|}
\hline $\begin{array}{c}\text { Faktörün } \\
\text { Adı }\end{array}$ & Soru & $\begin{array}{l}\text { Faktör } \\
\text { Ağırlığı }\end{array}$ & $\begin{array}{c}\text { Faktör } \\
\text { Açıklayıcılığı }\end{array}$ & Güvenilirlik & Sig. \\
\hline \multirow{4}{*}{$\begin{array}{c}\text { Motivasyon } \\
\text { unsurları }\end{array}$} & Ev sahipliği & 0.777 & \multirow{4}{*}{14.056} & \multirow{4}{*}{0,619} & \multirow{4}{*}{0.000} \\
\hline & Medeni durum & 0.725 & & & \\
\hline & Araba sahipliği & 0.682 & & & \\
\hline & Çocuk sahipliği & 0.615 & & & \\
\hline \multirow{5}{*}{$\begin{array}{c}\text { Banka } \\
\text { ürünleri } \\
\text { kullanım } \\
\text { alışkanlığ1 }\end{array}$} & Gelir/Birikim ilişkisi & 0.752 & \multirow{5}{*}{14.001} & \multirow{5}{*}{0,685} & \multirow{5}{*}{0.000} \\
\hline & Ek gelir harcama alışkanlığ & 0.730 & & & \\
\hline & $\begin{array}{c}\text { Acil durumlar için para tutma } \\
\text { alışkanlığı }\end{array}$ & 0.664 & & & \\
\hline & Vadeli Hesap sahipliği & 0.595 & & & \\
\hline & Kredi sahipliği & 0.468 & & & \\
\hline \multirow{4}{*}{ Yaşam tarzı } & Dışarıda yemek alışkanlığı & 0.715 & \multirow{4}{*}{13.306} & \multirow{4}{*}{0,616} & \multirow{4}{*}{0.000} \\
\hline & Kültürel faaliyet alışkanlığ1 & 0.705 & & & \\
\hline & Yurtdışı tatil alışkanlığ1 & 0.701 & & & \\
\hline & Spor alışkanlığ & 0.533 & & & \\
\hline \multirow{3}{*}{$\begin{array}{l}\text { Borçlanma } \\
\text { alışkanlığı }\end{array}$} & $\begin{array}{c}\text { Banka kartı ya da kredi kartı } \\
\text { tercihi }\end{array}$ & -0.796 & \multirow{3}{*}{11.558} & \multirow{3}{*}{0,608} & \multirow{3}{*}{0.000} \\
\hline & $\begin{array}{c}\text { Kredi kartı bakiye kullanım } \\
\text { alışkanlığı }\end{array}$ & 0.777 & & & \\
\hline & $\begin{array}{c}\text { Kredi kartı adet kullanım } \\
\text { alışkanlığ } 1\end{array}$ & 0.678 & & & \\
\hline \multicolumn{3}{|c|}{ Toplam } & 52,921 & $\mathbf{0 , 7 3 7}$ & 0.000 \\
\hline
\end{tabular}

Tablo 7'den görüleceği üzere, her bir faktörün güvenirlik testi 0,60 'dan büyüktür. Söz konusu sonuçlar analizin istatistiksel olarak anlamlı olduğunu göstermektedir.

\subsubsection{Hipotez Testleri}

Çalışmanın bu bölümünde, anket sorularına yönelik alınan cevaplar hipotez temelli ele alınacaktır.

H10: Bireylerin gelirlerine göre tasarruf değerleri eşittir.

H11 : Bireylerin gelirlerine göre tasarruf değerleri eşit değildir.

H10 hipotezi tek yönlü ANOVA testi ile sınanmıştır. Tablo 8'den görüleceği üzere, test sonucunda elde edilen olasılık (prob.-p) değeri 0.05'ten küçüktür. Bunun sonucunda H10 hipotezi reddedilmiştir. Sonuç olarak bireylerin gelir düzeyi arttıkça tasarruf eğilimi artmaktadır.

Tablo 8. Gelir ve Tasarruf Eğilimi Anova Çıktısı

\begin{tabular}{|c|c|c|c|}
\hline Gelir & $\mathbf{N}$ & Ortalama & Sig. (prob. değeri) \\
\hline $1,000-3,000 \mathrm{TL}$ & 47 & 0.61 & \\
\hline $3,001-5,000 \mathrm{TL}$ & 60 & 1.55 & 0.000 \\
\hline $5,001-10,000 \mathrm{TL}$ & 100 & 1.75 & \\
\hline 10,001 TL ve üzeri & 82 & 1.99 & \\
\hline Toplam & $\mathbf{2 8 9}$ & $\mathbf{1 . 5 9}$ & \\
\hline
\end{tabular}

H20: Kadın ve erkeklerin tasarruf eğilimi eşittir.

H21: Kadın ve erkeklerin tasarruf eğilimi eşit değildir.

$\mathrm{H} 2{ }_{0}$ hipotezi bağımsız gruplar t-testi ile sınanmıştır. Test sonucunda elde edilen p değeri 0.05 'ten büyüktür. Sonuç olarak $\mathrm{H} 20$ hipotezi kabul edilmiştir. Dolayısı ile cinsiyet ile tasarruf arasında herhangi bir ilişki tespit edilememiştir.

H30: Bireylerin eğitim düzeylerine göre tasarruf değerleri eşittir.

H3 1 : Bireylerin eğitim düzeylerine göre tasarruf değerleri eşit değildir. 
$\mathrm{H} 3_{0}$ hipotezi tek yönlü anova testi ile sınanmıştır. Tablo 9'dan görüleceği üzere, test sonucunda elde edilen $\mathrm{p}$ değeri 0.05 ’ten küçüktür. Bunun sonucunda $\mathrm{H} 3{ }_{0}$ hipotezi reddedilmiştir. Sonuç olarak eğitim düzeyi arttıkça tasarruf eğilimi artmaktadır.

Tablo 9. Eğitim seviyesi ve Tasarruf Eğilimi Anova Çıktısı

\begin{tabular}{|c|c|c|c|}
\hline Ĕgitim Seviyesi & $\mathbf{N}$ & Ortalama & Sig. (p değeri) \\
\hline Ortaokul & 13 & 0.62 & \\
\hline Lise & 15 & 0.87 & 0.01 \\
\hline Ön Lisan/Lisans & 151 & 1.64 & \\
\hline Yüksek Lisans/Doktora & 110 & 1.73 & \\
\hline Toplam & $\mathbf{2 8 9}$ & $\mathbf{1 . 5 9}$ & \\
\hline
\end{tabular}

H4, : Bireylerin hayat tarzlarına göre tasarruf değerleri eşittir.

H41: Bireylerin hayat tarzlarına göre tasarruf değerleri eşit değildir.

Yukarıda yer verilen hipotezler alt hipotez bazında ele alınacaktır.

H4-10: Bireylerin spor alışkanlıklarına göre tasarruf değerleri eşittir.

H4-11: Bireylerin spor alışkanlıklarına göre tasarruf değerleri eşit değildir.

H4- $1_{0}$ hipotezi tek yönlü anova testi ile sınanmıştır. Test sonucunda elde edilen p değeri 0.05 'ten büyüktür. Sonuç olarak H4-10 hipotezi kabul edilmiştir. Dolayısı ile spor alışkanlığı ile tasarruf arasında istatiksel bir ilişki bulunamamıştır.

H4-2 0 : Bireylerin dışarıda yemek yeme alışkanlıklarına göre tasarruf değerleri eşittir.

H4-2 1 : Bireylerin dışarıda yemek yeme alışkanlıklarına göre tasarruf değerleri eşit değildir.

H4-2 $2_{0}$ hipotezi tek yönlü anova testi ile sınanmıştır. Tablo 10'dan görüleceği üzere, test sonucunda elde edilen p değeri 0.05 ’ten küçük olduğu belirlenmiştir. Sonuç olarak H4-2 hipotezi reddedilmiştir. Dolayısı ile dişarıda yeme alışkanlığ1 ortalama olan bireylerin tasarruf eğiliminin diğer bireylere göre daha düşük olduğu görülmektedir. Dışarıda yeme alışkanlığı çok az olan bireylerin düşük tasarruf yapmasının arkasındaki en temel nedenin düşük gelir seviyesi olduğu düşünülmektedir. Diğer bir ifade ile geliri düşük olan kişiler tasarruf yapamadıkları gibi ilgili kişilerin dışarıda da yemek alışkanlığı bulunmamaktadır. Diğer bir unsur da yemek alışkanlığı yüksek olan bireylerin gelirleri yüksek olsa da tasarruf yapamamasıdır.

Tablo 10. Dişarıda Yeme Alışkanlığı ve Tasarruf Eğilimi Anova Çıktısı

\begin{tabular}{|c|c|c|c|}
\hline Dışarıda Yemeğe Çıkma Sayısı & N & Ortalama & \multirow{2}{*}{0} \\
\hline $0-1$ & 42 & 1.05 & \multirow{2}{*}{0.017} \\
\hline $2-4$ & 116 & 1.72 \\
\hline 5-10 & 83 & 1.67 & \\
\hline 10 ve üzeri & 48 & 1.58 \\
\hline Toplam & $\mathbf{2 8 9}$ & $\mathbf{1 . 5 9}$ & \\
\hline
\end{tabular}

H4-30: Bireylerin kültürel alışkanlıklarına göre tasarruf değerleri eşittir.

H4-30: Bireylerin kültürel alışkanlıklarına göre tasarruf değerleri eşit değildir.

H4-3 $3_{0}$ hipotezi tek yönlü anova testi ile sınanmıștır. Test sonucunda elde edilen p değeri 0.05 ’ten büyük olduğu belirlenmiştir. Sonuç olarak H4-30 hipotezi kabul edilmiştir. Dolayısı ile kültürel alışkanlıklar ile tasarruf arasında istatistiksel anlamda bir ilişki bulunamamıştır.

H4-40: Bireylerin yurtdışı tatil alışkanlıklarına göre tasarruf değerleri eşittir.

H4-40: Bireylerin yurtdışı tatil alışkanlıklarına göre tasarruf değerleri eşit değildir.

H4-4 $4_{0}$ hipotezi tek yönlü anova testi ile sınanmıştır. Test sonucunda elde edilen p değeri 0.05 ’ten büyüktür. Sonuç olarak H4-4 $4_{0}$ hipotezi kabul edilmiştir. Dolayısı ile yurtdışı tatil alışkanlıkları ile tasarruf arasında istatiksel bir farklılık bulunamamıştır.

H50: Evli ve Bekâr bireylerin tasarruf eğilimi eşittir.

H50: Evli ve Bekâr bireylerin tasarruf eğilimi eşit değildir. 
$\mathrm{H} 5_{0}$ hipotezi bağımsız gruplar t testi ile sınanmıştır. Test sonucunda elde edilen p değeri 0.05 'ten büyüktür. Sonuç olarak $\mathrm{H} 50$ hipotezi kabul edilmiştir. Dolayısı ile bireylerin tasarruf eğilimi ile medeni durum arasında herhangi bir ilişki tespit edilememiştir.

H60: Çocuk sahibi olan ve olmayan bireylerin tasarruf eğilimi eşittir.

H60: Çocuk sahibi olan ve olmayan bireylerin tasarruf eğilimi eşit değildir.

H6 $6_{0}$ hipotezi tek yönlü anova testi ile sınanmıştır. Test sonucunda elde edilen p değeri 0.05 'ten büyüktür. Sonuç olarak $\mathrm{H}_{0}$ hipotezi kabul edilmiştir. Dolayısı ile çocuk sahibi olma durumu ile tasarruf arasında istatiksel bir ilişki bulunamamıştır.

H70: Ev sahipliği ile tasarruf arasında ilişki yoktur.

H70: Ev sahipliği ile tasarruf arasında ilişki vardır.

H7 $7_{0}$ hipotezi bağımsız gruplar t testi ile sınanmıștır. Test sonucunda elde edilen p değeri 0.05 'ten büyüktür. Sonuç olarak $\mathrm{H} 7_{0}$ hipotezi kabul edilmiştir. Dolayısı ile ev sahipliği ile bireylerin tasarruf eğilimi arasında bir ilişki bulunamamıştır.

H80: Araç sahipliği ile tasarruf arasında ilişki yoktur.

H80: Araç sahipliği ile tasarruf arasında ilişki vardır.

H8 0 hipotezi bağımsız gruplar t testi ile sınanmıştır. Test sonucunda elde edilen p değeri 0.05 'ten büyüktür. Sonuç olarak $\mathrm{H} 80$ hipotezi kabul edilmiştir. Dolayısı ile bireylerin araç sahipliği ile tasarruf eğilimi arasında herhangi bir ilişki tespit edilememiştir.

H9: Borçlanma eğilimi yüksek olan bireyler ile olmayanların tasarrufu eşittir.

H9: Borçlanma eğilimi yüksek olan bireyler ile olmayanların tasarrufu eşit değildir.

Yukarıda yer verilen hipotezler alt hipotez bazında ele alınacaktır.

H9-10:Kredi kartı adedi yüksek olan bireyler ile olmayanların tasarrufu eşittir.

H9-1 0 :Kredi kartı adedi yüksek olan bireyler ile olmayanların tasarrufu eşit değildir.

H9-1 $1_{0}$ hipotezi tek yönlü anova testi ile sınanmıştır. Test sonucunda elde edilen p değeri 0.05 'ten büyüktür. Sonuç olarak H9-1 $1_{0}$ hipotezi kabul edilmiştir. Dolayısı ile kredi kartı kullanım adedi ile bireysel tasarruf arasında herhangi bir ilişki bulunamamıştır.

H9-20: Kredi kartı kullanım hacmi yüksek olan bireyler ile olmayanların tasarrufu eşittir.

H9-20: Kredi kartı kullanım hacmi yüksek olan bireyler ile olmayanların tasarrufu eşit değildir.

H9-2 $2_{0}$ hipotezi tek yönlü anova testi ile sınanmıştır. Tablo 11'den görüleceği üzere, test sonucunda elde edilen p değeri 0.05 'ten küçüktür. Sonuç olarak H9-2 $2_{0}$ hipotezi reddedilmiştir. Dolayısı ile kredi kartı kullanımı düşük olan bireylerin tasarruf etme eğilimi daha yüksektir.

Tablo 11. Kredi Kartı Kullanım Hacmi ve Tasarruf Eğilimi Anova Çıktısı

\begin{tabular}{|c|c|c|c|}
\hline Kredi Kartı Kullanım Hacmi & $\mathbf{N}$ & Ortalama & Sig. (p değeri) \\
\hline$\% 0-\% 20$ & 108 & 1.78 & \\
\hline$\% 21-\% 50$ & 121 & 1.74 & 0.000 \\
\hline$\% 51-\% 100$ & 51 & 1.02 & \\
\hline \%101 ve üzeri & 9 & 0.44 & \\
\hline Toplam & $\mathbf{2 8 9}$ & $\mathbf{1 . 5 9}$ & \\
\hline
\end{tabular}

H9-30: Kredi kartı ile Banka kartı kullanmayı tercih eden bireylerin tasarrufu eşittir.

H9-30: Kredi kartı ile Banka kartı kullanmayı tercih eden bireylerin tasarrufu eşit değildir.

H9-30 hipotezi bağımsız gruplar t testi ile sınanmıştır. Test sonucunda elde edilen p değeri 0.05 'ten büyüktür. Sonuç olarak H9- $3_{0}$ hipotezi kabul edilmiştir. Dolayısı ile bireysel tasarruflar ile banka kartı ve kredi kartı kullanım tercihi arasında herhangi bir ilişki tespit edilememiştir.

H100: Ek gelirlerini harcama alışkanlığı farklı olan bireylerin tasarruf eğilimi eşittir.

H100: Ek gelirlerini harcama alışkanlığı farklı olan bireylerin tasarruf eğilimi eşit değildir. 
$\mathrm{H} 10_{0}$ hipotezi tek yönlü anova testi ile sınanmıştır. Tablo 12'den görüleceği üzere, test sonucunda elde edilen p değeri 0.05 'ten küçüktür. Sonuç olarak $\mathrm{H} 10_{0}$ hipotezi kabul edilmiştir. Dolayısı ile bireylerin ek gelirlerini harcama alışkanlığı ile bireysel tasarruflar arasında bir ilişki bulunmaktadır.

Tablo 12. Bireylerin Ek Gelirlerini Harcama Alışkanlığı ve Tasarruf Eğilimi Anova Çıktısı

\begin{tabular}{|c|c|c|c|}
\hline Bireylerin Ek Gelirlerini Harcama Alışkanlığı & N & Ortalama & \multirow{2}{*}{ Sig. (p değeri) } \\
\cline { 1 - 2 } Harcarım & 23 & 0.87 & \multirow{2}{*}{0.000} \\
\hline Borçlarımı öderim & 96 & 0.85 & \\
\hline Harcamam, birikim yaparım & 170 & 2.1 & \\
\hline
\end{tabular}

\section{Sonuç}

Birçok gelişmekte olan ülke için olduğu gibi Türkiye için de tasarrufların artırılması önem taşımaktadır. Bu önemin temelinde Türkiye'nin gelişmekte olan bir ülke olması, ekonomisini büyütmesi için yatırımlara ihtiyaç duyması ve yatırımların finansmanı için kaynak ihtiyacı yatmaktadır. Yatırımların finansmanı için yurt dışı borçlanmalar ekonomik kırılganlık yarattığı için ülke içi tasarruflarla yatırımların finanse edilmesi önem taşımaktadır. Bu kapsamda ülke içi finansmanın temel kaynağını tasarruflar oluşturmaktadır.

Türkiye'de yurt içi tasarruflar önemli ölçüde düşüş göstermektedir. 1975 yıllarında GSYH'nin \%25'i seviyelerinde olan tasarruflar son y1llarda önemli ölçüde düşüş göstermiştir. Hatta 1993, 1997, 2000, 2001, 2004 ve 2009 gibi ulusal ya da küresel krizlerin yaşandığı yıllarda kamu tasarruflarının negatif yaşanması sebebi ile toplam tasarruflar önemli ölçüde azalmış ve 2014 yılında GSYH'nin \%14,9'u olarak gerçekleşmiştir.

Türkiye'de düşük olan tasarrufların, son y1llarda önemli ölçüde düşüş göstermesi üzerine hazırlanan bu çalışmada tasarruf düşüklügünün nedenleri belirlenmeye çalışılmıştır. Bu kapsamda tasarruflara etki eden unsurları incelemek üzere Türkiye'de yaşayan 289 katılımcı ile anket çalışması yapılmıştır. Söz konusu çalışmada gelir, cinsiyet, eğitim düzeyi, spor alışkanlığı, dışarıda yemek yeme alışkanlığı, kültürel alışkanlıklar, yurtdışı tatil alışkanlığı, medeni durum, çocuk sahipliği, ev ve araç sahipliği, kredi kartı kullanım adedi ve hacmi, banka kartı ya da kredi kartı kullanım tercihi ve düzenli geliri dışında gelen geliri harcama alışkanlıkları ile tasarruf alışkanlığ arasındaki ilişki araştırılmıştır.

Araştırmada öncelikle katılımcılara farklı konularda 30 adet ifadeye ne derece katıldıkları sorgulanmıştır. Sonrasında verilen cevaplara göre ilgili ifadelerin doğal gruplarını tespit edebilmek amacıyla Faktör Analizi uygulanmış ve kavramsal anlamlılı̆̆ negatif olarak etkileyen ifadeler çıkartılmıştır. Sonuçta 16 adet ifade 4 faktör altında toplanmıştır. Bu faktörlerin toplam varyans açıklayıcılığı kabul edilebilir sınırlar dâhilinde \%52,92 olarak hesaplanmıştır.

Araştırmanın ikinci bölümünde, değişkenler ve tasarruflar arasındaki ilişkiler incelenmiştir. Bu süreçte anova testi ve t-testi yöntemleri kullanılmıştır. Hipotez testleri sonucunda geliri artan bireylerin tasarruf eğiliminin arttığ belirlenmiştir. Ayrıca eğitim düzeyi ile tasarruf eğilimi arasında aynı yönde bir ilişki bulunmuştur. Diğer bir ifade ile eğitim düzeyi yüksek olan bireyler daha fazla tasarruf yapmaktadırlar. Dolayısı ile ülkenin eğitim düzeyi arttıkça düşük tasarruf probleminin çözümüne katkı sağlayacaktır.

Keynes, gelişmekte olan ülkelerdeki yüksek marjinal tüketim eğilimi yasasında bireylerin ellerine geçen her 1 TL'nin yaklaşık \% 70'ini harcarken \%30'unu tasarruf ettiklerini ortaya koymuştur. Bu çalışmada ise dışarıda yemek yeme alışkanlığı ve kredi kartı kullanım hacmi yüksek olan bireylerde tasarruf eğiliminin daha düşük olduğu belirlenmiştir. Ulaştığımız sonuç Keynes'in kuramı ile tutarlı görünmektedir. Dışarıda yemek yeme alışkanlığı ve yüksek hacimli kredi kartı kullanımına yönelik yapılacak sınırlayıcı düzenlemelerin bireysel tasarrufların artmasına katkı sağlayacağı kanaatine ulaşılmıştır. Ayrıca ek bir gelir elde edilmesi halinde, tasarruf etmek yerine harcamayı tercih eden kişilerin, normal yaşantılarında da tasarruf yapmadıkları belirlenmiştir. Söz konusu sonuç, tasarruf yapmanın önemi konusunda vatandaşların bilinçlendirilmesine yönelik çalışmalar yapılması gerektiğini göstermektedir

Diğer taraftan cinsiyet, medeni durum ve çocuk sahipliği gibi konular ile tasarruflar arasında istatistiksel olarak anlamlı bir ilişki tespit edilmemiştir. Spor, yurtdışı tatil ve kültürel alışkanlıkların da tasarruf üzerinde etkisi olmadığı sonucuna ulaşılmıştır. Ayrıca ev veya araç sahipliği ile tasarruf oranları arasında da bir ilişki bulunamamıştır.

Bu çalışmada Türkiye'de yaşayan bireylerin tasarruf eğilimleri ele alınmıştır. Böylece ülkemizde önemli bir husus olan düşük tasarruf soruna neden olan faktörler belirlenmiştir. Düşük tasarruf sorununu çözülebilmesi ve tasarrufların artırılabilmesi için bu çalışmada belirtilen hususların, tasarrufların artırılmasına yönelik aksiyon alınmasında düzenleyici otoritelere yol gösterici olacağı düşünülmektedir. 


\section{KAYNAKÇA}

Anong, S. T. ve DeVaney, S. A. (2010). Determinants of adequate emergency funds including the effects of seeking professional advice and industry affiliation. Family and Consumer Sciences Research Journal, 38(4), 405-419.

Atalay, K. Bakhtiar, F. Cheung, S. ve Slonim, R. (2014). Savings and prize-linked savings accounts. Journal of Economic Behavior \& Organization, 107, 86-106.

Athukorala, P. C. ve Sen, K. (2004). The determinants of private saving in India. World Development, 32(3), 491503.

Avery, R. ve Kennickell, A. B. (1991). Household saving in the U.S. Review of Income and Wealth, 37, 409-432.

Barış, Serap \& Şahin, Metehan. (2017). Tasarruf davranışını etkileyen faktörlerin belirlenmesi: Tokat'ta kamu çalışanlarına yönelik bir uygulama. V. Anadolu International Conference in Economics, 11-13 Mayıs, Eskişehir.

Bebczuk, R., Gasparini, L., Garbero, N. ve Amendolaggine, J. (2015). Understanding the determinants of household saving: Micro evidence for Latin America (No. 0189). CEDLAS, Universidad Nacional de La Plata.

Bosworth, B. P., Burtless, G. ve Sabelhaus, J. (1991). The decline in saving: Evidence from household surveys. Brookings Papers on Economic Activity, 1, 183-256.

Browning, M. (2000). The saving behaviour of a two-person household. The Scandinavian Journal of Economics, 102, 235-251.

Browning, M. ve Lusardi, A. (1996). Household saving: Micro theories and micro facts. Journal of Economic Literature, 34, 1797-1855.

Carvalho, S. L., Prina, S. ve Sydnor, J. (2016). The effect of saving on risk attitudes and intertemporal choices. Journal of Development Economics, 120, 41-52.

Ceritoğlu, E. ve Eren, O. (2014). The Effects of demographic and social changes on household savings in Turkey. Central Bank Review, 14, 15-33.

Chen, C., ve DeVaney, S. A. (2001). The effect of life cycle stages and saving motives on the probability of emergency fund adequacy. In J. M. Hogarth (Ed.), Proceedings of the Association for Financial Counseling and Planning Education (pp. 176-185). Columbus, OH: AFCPE.

Cilasun, S. M. ve Kırdar, M. G. (2009). Türkiye'de hanehalklarının gelir, tüketim ve tasarruf davranışlarının yatay kesitlerle bir analizi. İktisat Işletme ve Finans, 24, 9-46.

Corbo, V. ve Schmidt-Hebbel, K. (1991). Public policies and saving in developing countries. Journal of Development Economics, 36, 89-115.

Cronbach, L. J. (1951). Coefficient alpha and the internal structure of tests. Psychometrika, 16 (3), $297-334$.

Çokluk, Ö., Şekercioğlu, G., \& Büyüköztürk, Ş. (2012). Sosyal Bilimler İçin Çok Değişkenli İstatistik: SPSS ve Lisrel Uygulamaları. Ankara: Pegem Akademi Yayıncılık.

Çolak, Ö. F. ve Öztürkler H. (2012). Tasarrufun belirleyicileri: Küresel tasarruf eğiliminde değişim ve Türkiye'de hanehalkı tasarruf eğiliminin analizi. Bankacılar Dergisi, 82, 3-44.

Du Q. ve Wei S. J. (2013). A theory of the competitive saving motive. Journal of International Economics, 91, 275-289.

Dünya Bankası (2017). World bank open data, https://data.worldbank.org, Erişim tarihi: 05.11.2017.

Düzgün, R. (2009). Türkiye'de özel tasarrufun belirleyicileri. Erciyes Üniversitesi İktisadi ve İdari Bilimler Fakültesi Dergisi, 32, 173-189.

Edwards, S. (1995). Why are saving rates so different across countries? An international comparative analysis (No. w5097). National Bureau of Economic Research.

Feldstein, M. S. ve Horioka, C. Y. (1979). Domestic savings and international capital flows. Econ. J., 90, 314-329.

Finlay, R. ve Price, F. (2015). Household saving in Australia. The BE Journal of Macroeconomics, 15, 677-704

Fisher J. P. ve Anong T. S. (2012). Relationship of saving motives to saving habits. Journal of Financial Counseling and Planning, 23, 63-79.

Friedman, M. (1957). The permanent income hypothesis. A theory of the consumption function, 20-37.

Gärling, T., Kirchler, E., Lewis, A. ve Raaij, F. V. (2010). Psychology, financial decision making, and financial crises. Psychological Science in the Public Interest, 3-56.

Hamarat, B. ve Özen, E. (2015). Türkiye'de tasarruf tercihlerini etkileyen değişkenlerin kanonik korelasyon analizi ile belirlenmesi. Journal of Life Economics, 3, 47-74.

Hashim, D. B., Pin, F. B. ve Isa, M. Y. B. M. (2017). Factors influencing savings rate in Malaysia. International Journal of Economics and Finance, 9(6), 52-56.

Hira, T. (1987). Households' financial management factors influencing solvency and satisfaction. The Journal of Japan Society of Household Economics, 10, 199-210.

Hirsh J. (2015). Extraverted populations have lower savings rates. Personality and Individual Differences, 81, 162168. 
Kalaycı, Ş. (2009). SPSS uygulamalı çok değişkenli istatistik teknikleri. Ankara: Asil Yayın Dağıtım.

Kalkınma Bakanlığı (2017). Yatırım ve tasarruf: ekonomik ve sosyal göstergeler, http://www.kalkinma.gov.tr/Pages/EkonomikSosyalGostergeler.aspx, Erişim tarihi: 05.11.2017.

Keynes, J. M., (1980). Istihdam, faiz ve para genel teorisi. Çeviren: Asım Baltacıgil. Minnetoğlu Yayınları.

Kwack, S. Y. ve Lee, Y. S. (2005). What determines saving rates in Korea? The role of demography. Journal of Asian Economics, 16, 861-873.

Le Blanc, J., Porpiglia, A., Teppa, F., Zhu, J. ve Ziegelmeyer, M. (2015). Household saving behaviour and credit constraints in the Euro area. European Central Bank Working Paper Series.

Lee, S., Park, M. ve Montalto, C. P. (2000). The effect of family life cycle and financial management practices on household saving patterns. Journal of Korean Home Economics Association English Edition, 1, 79-92.

Livingstone, S. ve Lunt, P. (1993). Savers and borrowers: Strategies of personal financial management. Human Relations, 46, 943-985.

Mankiw, N. (2014). Principles of macroeconomics. Cengage Learning.

Masson, P. R., Bayoumi, T. ve Samiei, H. (1998). International evidence on the determinants of private saving. The World Bank Economic Review, 12, 483-501.

Matur, E. P., Sabuncu, A. ve Bahçeci, S. (2012). Determinants of private saving and interaction between public \& private savings in Turkey. Topics in Middle Eastern and African Economies, 14, 101-125.

Mirach, T. H. ve Hailu, Y. M. (2014). Determinants of Household Saving In Ethiopia: A Case of North Gondar Zone Amhara Regional State. International Journal of Development and Economic Sustainability, 2, $37-$ 49.

Nosi, C., D’Agostino A., Pagliuca, M. M. ve Pratesic, C. A. (2014). Saving for old age: Longevity annuity buying intention of Italian Young adults. Journal of Behavioral and Experimental Economics, 51, 85-98.

Özcan, K. M., Gunay, A. ve Ertac, S. (2003). Determinants of private savings behaviour in Turkey. Applied Economics, 35(12), 1405-1416.

Özlale, Ü. ve Karakurt, A. (2012).Türkiye'de tasarruf açığının nedenleri ve kapatılması için politika önerileri. Bankacllar Dergisi, 83, 1-33.

Paiva, C. ve Jahan, S. (2003). An empirical study of private saving in Brazil. Brazilian Journal of Political Economy, 23, 121-132.

Pan, Y. (2016). Understanding the rural and urban household saving rise in China. Regional Science and Urban Economics, 56, 46-59.

Rha, J. Y., Montalto, C. P. ve Hanna, S. D. (2006). The effect of self-control mechanisms on household saving behavior. Financial Counseling and Planning, 17, 3-16.

Schmidt-Hebbel, K., Webb, S. B. ve Corsetti, G. (1992). Household saving in developing countries: First crosscountry evidence. The World Bank Economic Review, 6, 529-547.

Smith, A. (1997). Ulusların zenginliği, Çeviren: Ayşe Yunus ve Mehmet Bakırcı. Alan Yayıncılık, İstanbul.

Şahin, D. (2017). Farklı gelir gruplarındaki ülkelerde tasarrufların belirleyicileri: Panel veri analizi. Uluslararası İktisadi ve Ídari Incelemeler Dergisi, 19, 133-148.

Şengür, M. ve Taban, S. (2016). Türkiye'de hanehalkı tasarruflarının gelir dışındaki belirleyicileri. Optimum Ekonomi ve Yönetim Bilimleri Dergisi, 3, 29-53.

Thaler, R. H. (1994). Psychology and savings policies. The American Economic Review, 84(2), 186-192.

Türkiye Cumhuriyet Merkez Bankası (2017), GSYİH-harcama yöntemiyle-cari fiyatlarla, https://evds2.tcmb.gov.tr/index.php?/evds/serieMarket/\#collapse_21, Erişim tarihi: 05.11.2017.

Uçgun, S. (2017). Türkiye'de makroekonomik faktörlerin 2000-2014 döneminde yurtiçi tasarruflara etkisi. Vizyoner Dergisi, 8(18), 111-126.

Uygur, E. (2012). Türkiye'de tasarrufların seyri ve etkileyen bazı unsurlar (No. 2012/108). Discussion Paper, Turkish Economic Association.

Van Rijckeghem, C. ve Üçer, M. (2009). The evolution and determinants of the Turkish private saving rate: What lessons for policy?. Economic Research Forum, TÜSİAD, Koç Üniversitesi.

Wakabayashi, M. ve MacKellar, F. L. (1999). Demographic trends and household saving in China (No. ir99057).

Wan, J. (2015). Household savings and housing prices in china. The World Economy, 38, 172-192.

Xiao, J. J. ve Anderson, J. G. (1997). Hierarchical financial needs reflected by household financial asset shares. Journal of Family and Economic Issues, 18, 333-355.

Xiao, J. J. ve Noring, F. E. (1994). Perceived saving motives and hierarchical financial needs. Financial Counseling and Planning, 5, 25-44.

Yuh, Y. ve Hanna, S. D. (2010). Which households think they save?. Journal of Consumer Affairs, 44, 70-97.

Zhuk, M. (2015). Macroeconomic Determinants of Household Savings in Ukraine. Economics and Sociology, 8, 41-54.

Ekler

Ek 1. Anket Soruları 


\begin{tabular}{|c|c|c|}
\hline No & Soru & Cevap Seçenekleri \\
\hline 1 & Aylık geliriniz ne kadarıyla birikim yaparsınız? & $\% 0-\% 1 ; \% 2-\% 10 ; \% 11-\% 20 ; \% 21-\% 50 ; \% 51-\% 100$ \\
\hline 2 & 5 sene sonra birikim yapmayı planlıyor musunuz? & Evet; Hayır \\
\hline 3 & \begin{tabular}{|l}
$\begin{array}{l}\text { Sevdiklerinizi birikim yapması için destekler } \\
\text { misiniz? }\end{array}$
\end{tabular} & Evet; Hayır \\
\hline 4 & Acil durumlar için kenarda para tutar mısınız? & Evet; Hayır \\
\hline 5 & Bireysel emeklilik hesabınız var mı? & Evet; Hayır \\
\hline 6 & Krediniz var mi? & Evet; Hayır \\
\hline 7 & Vadeli hesabınız var mı? & Evet; Hayır \\
\hline 8 & Hangisini daha çok kullanıyorsunuz? & Kredi Kartı; Banka Kart1 \\
\hline 9 & Eviniz var $\mathrm{m}$ ? & Evet; Hayır \\
\hline 10 & Arabanız var mi? & Evet; Hayır \\
\hline 11 & Çocuğunuz var mı? & Yok; $1 ; 2 ; 3$ ve üzeri \\
\hline 12 & $\begin{array}{l}\text { Tatile gitmek istiyorsunuz ancak yeterli paranız yok, } \\
\text { ne yaparsınız? }\end{array}$ & $\begin{array}{l}\text { Kredi çekerim; Yeterli para biriktirene kadar } \\
\text { beklerim; Tatile gitmem }\end{array}$ \\
\hline 13 & Sigara kullanıyor musunuz? & Evet; Hayır \\
\hline 14 & Ayda kaç kez dışarda akşam yemek yersiniz? & $0-1 ; 2-4 ; 5-10 ; 11$ ve üzeri \\
\hline 15 & Ayda kaç kez sinema/tiyatro/konsere gidersiniz? & $0-1 ; 2-4 ; 5$ ve üzeri \\
\hline 16 & Yılda kaç kere yurtdışı tatili yaparsınız? & $0-1 ; 2-5 ; 6$ ve üzeri \\
\hline 17 & $\begin{array}{llll}\text { Yllda kaç kere kendiniz } & \text { için } \\
\text { doktor/hastane/polikliniğe gidersiniz? } & \\
\end{array}$ & $0-1 ; 2-4 ; 5-10 ; 11$ ve üzeri \\
\hline 18 & Cinsiyetiniz & Kadın; Erkek \\
\hline 19 & Aylık hanehalkı geliriniz (TL) & $\begin{array}{l}0-1.000 ; 1.001-3.000 ; 3.001-5.000 ; 5.001-10.000 ; \\
10.001 \text { ve üzeri }\end{array}$ \\
\hline 20 & Çalışma durumunuz? & $\begin{array}{l}\text { Çalışmıyor; Öğrenci; Kamu çalışanı; Özel sektör } \\
\text { calıșanı; Serbest meslek }\end{array}$ \\
\hline 21 & $\begin{array}{l}5 \text { y1l sonra maaşınızın ne kadar artacağını } \\
\text { düșünüyorsunuz? }\end{array}$ & $\begin{array}{l}\text { Değişmez; \%1-\%10; \%11-\%20; \%21-\%50; \%51- } \\
\% 100\end{array}$ \\
\hline 22 & Aşağıdakilerden hangisi tercih edersiniz? & $\begin{array}{l}\text { Anapara korumalı düşük faiz getirisi olan bankacılık } \\
\text { ürünleri; Anaparanın belirli bir kısmını kaybetme } \\
\text { ihtimali olan orta faiz getirili bankacılık ürünleri; } \\
\text { Anaparanın tümünü kaybetme ihtimali olan yüksek } \\
\text { faiz getirili bankacılık ürünleri }\end{array}$ \\
\hline 23 & Eğitim durumunuz? & $\begin{array}{l}\text { Ortaokul; Lise, Ön lisans/Lisans; } \\
\text { Lisans/Doktora }\end{array}$ \\
\hline 24 & 5 sene içerisinde ev almayı planlıyor musunuz? & Evet; Hayır \\
\hline 25 & Kaç adet kredi kartı kullanıyorsunuz? & $0-1 ; 2-4 ; 5$ ve üzeri \\
\hline 26 & $\begin{array}{l}\text { Aylık kredi kartı harcamanız gelirinizin ne kadarını } \\
\text { oluşturuyor? }\end{array}$ & $\begin{array}{l}\% 0-\% 10 ; \% 11-\% 20 ; \% 21-\% 50 ; \% 51-\% 100 ; \% 101 \\
\text { ve üzeri }\end{array}$ \\
\hline 27 & $\begin{array}{lllll}\text { Ekstra } 3 \quad \text { maaş } & \text { ikramiye } & \text { alsanız } & \text { nasıl } \\
\text { değerlendirirsiniz? }\end{array}$ & $\begin{array}{l}\text { Harcamam, birikim yaparım; Borçlarımı öderim; } \\
\text { Harcarım }\end{array}$ \\
\hline 28 & Spor için aylık ortalama ne kadar ödersiniz (TL)? & $0 ; 1-100 ; 101-500 ; 501$ ve üzeri \\
\hline 29 & Medeni durumunuz? & Evli; Bekâr \\
\hline 30 & 5 yıl içerisinde çalışmama ihtimaliniz & $\% 1-\% 20 ; \% 21-\% 50 ; \% 51-\% 100$ \\
\hline
\end{tabular}

